\title{
The effect of exposure to suspended sediment in mortality of Corbicula fluminea (Müller, 1774) (Bivalvia: Corbiculidae)
}

\author{
Neves Fernando F. ${ }^{1}$, Lavrador Marco A. S. ${ }^{2}$, Costa Álvaro S. ${ }^{1}$, Avelar Wagner E. P. ${ }^{1}$ \\ ${ }^{1}$ Department of Biology, Faculty of Philosophy, Sciences and Languages of Ribeirão Preto, University of São Paulo, Brazil \\ ${ }^{2}$ Department of Physics and Chemistry of the Faculty of Pharmaceutical Sciences of Ribeirão Preto, University of São Paulo, Brazil \\ Email address: \\ proffernandoneves@terra.com.br (Neves F. F.)
}

\section{To cite this article:}

Neves Fernando F., Lavrador Marco A. S., Costa Álvaro S., Avelar Wagner E. P.. The Effect of Exposure to Suspended Sediment in Mortality of Corbicula Fluminea (Müller, 1774) (Bivalvia: Corbiculidae). American Journal of Life Sciences. Vol. 2, No. 3, 2014, pp. 150-154. doi: 10.11648/j.ajls.20140203.14

\begin{abstract}
The erosion of rural watersheds, especially in the rainy season, deposit sediments in the waterways, and subsequently brings about one of the most important physicochemical changes in our water resources: the rise in their turbidity parameters. For freshwater bivalves, changes in water turbidity have a significant impact because they are filter feeders and depend on stable water conditions to regulate their physiological functions. Our preliminary studies have already demonstrated Corbicula fluminea`s (Müller 1774) intolerance to increases the turbidity of the water. In the current paper, we conducted research in the watersheds of the Pardo and Mogi rivers (State of São Paulo - Brazil). Under laboratory conditions, we did not observe statistical differences in the mortality rate of $C$. fluminea to turbidity levels of 150,200 and 250 nephelometric turbidity units (NTU). Mortality rates of approximately $50 \%$ were observed when the specimens were exposed to these conditions for 96 to 120 hours. Results indicate that the species is sensitive or even intolerant to changes in turbidity, caused by suspended sediment, which explains the high mortality and the seasonal decline in the population of this species during rainy periods. The methodology used in this research, supported by the results produced, may indicate a new way of studying the decline of molluscan biodiversity that has been observed throughout Brazil.
\end{abstract}

Keywords: Pollution, Turbidity, Biodiversity, Riparian Vegetation, Mollusca

\section{Introduction}

Corbicula fluminea (Müller 1774) (Bivalvia: Corbiculidae), is an exotic species in Brazil. It was introduced into South America in 1970 [1], probably by means of ballast water from ships entering the Rio da Prata estuary. This species has been the subject of much research due to its capacity to spread over large areas and become an important competitor with native species of freshwater bivalve, potentially causing ecological imbalance. $C$. fluminea has attracted special attention from the academic community due to its negative economic impact and the potential risk it poses to native fauna. These events are results of its successful dispersal strategies and subsequent increased competition for space and food. High densities of this bivalve (over 200 individuals $/ \mathrm{m}^{2}$ ) have been found to be potentially harmful, both for channelling water and for hydroelectric power [2].
Freshwater bivalves generally live buried in muddy or sandy riverbeds, at depths which vary according to the size of the specimens. C. fluminea does not show any preference for a particular sediment texture [3] or substrate or vegetation cover, showing a high level of resistance to changes in physical-chemical parameters of water temperature and salinity [4]. The rainy season increases a river's flow measurement and the velocity of its current, which is associated with the resuspension of sediment particles [5] and the transportation of solutes caused by the erosion of the river margins [6]. These lead to an increase in the water's turbidity. Several studies have shown the influence of turbidity, specifically suspended sediments, on the life cycle of aquatic animals [7, 8, 9], which is the central concern of this study.

The factors causing the decline of bivalve populations are numerous and often interrelated [10]. However, while much of the literature involves scientific anatomy and functional morphology of bivalves [11-16] or addresses 
reproductive aspects $[17,18,19]$, there is still no scientific evidence in the literature that addresses the influence of suspended sediments on the mortality of bivalve populations.

To this end, the objective of this study was to analyse, under laboratory conditions, the mortality of $C$. fluminea in terms of the turbidity of the water and time of exposure, and evaluate how these factors influence the mortality of the species.

\section{Material and Methods}

\subsection{Sites Location}

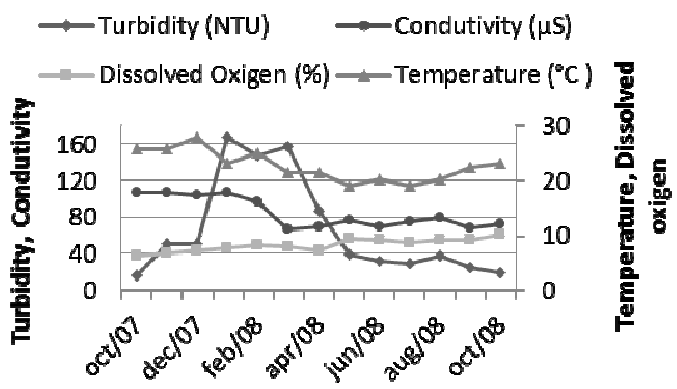

Figure 1
The study was conducted in two areas located in micro watersheds in the State of São Paulo, Brazil with the coordinates of $\left(21^{\circ} 10^{\prime} 44,9^{\prime \prime} \mathrm{S}\right.$ and $\left.47^{\circ} 34^{\prime} 30,5^{\prime \prime} \mathrm{W}\right)$ for the Pardo River and $\left(21^{\circ} 50^{\prime} 36,1^{\prime \prime S}\right.$ and $\left.47^{\circ} 29^{\prime} 44,5^{\prime \prime} \mathrm{W}\right)$ for the Mogi Guaçu River. In both sites, the following abiotic components were monitored monthly, from October 2007 to October 2008: dissolved oxygen (in percentage) and temperature (in Celsius) measured using a YSI 52 Oximeter (YSY Inc., USA); turbidity, analyzed with the aid of a 2100 portable Turbidimeter (Hach USA); and electrical conductivity (in $\mu \mathrm{S}$ ) obtained using a YSI 30 conductivity meter (YSY Inc, USA). (Figs 1 and 2).

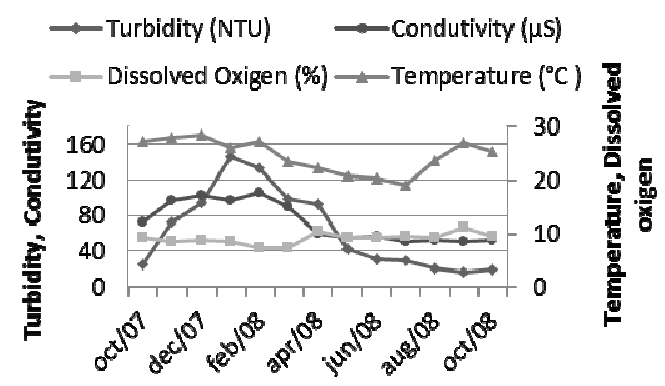

Figure 2

Figures 1 \& 2. Graphical representation of changes in abiotic parameters in the river Mogi-Guaçu (F.1) and river Pardo (F.2) between October 2007 to October 2008 .

\subsection{Specimen Collection and Acclimation}

At each study site, 200 specimens of C. fluminea were collected groping the riverbed sediment of both sites. Thus, the specimens collected were transported to the laboratory in coolers and packed separately in batches into asbestos boxes measuring $70 \times 70 \times 70 \mathrm{~cm}$. These containers allowed for the open circulation of water and were acclimatized to a temperature of $27^{\circ} \mathrm{C}$ for 72 hours. This temperature represents an average summer temperature for both the Mogi-Guaçu and Pardo rivers. During both the acclimation and experimental phases, the bivalves were fed, once a day, with one liter of microalgae added to the water of the containers, mainly chlorella collected at the study sites and cultured in the laboratory.

\subsection{Experiment to Determine the Mortality in $C$. Fluminea}

An experiment was designed to investigate the effect of duration of exposure to turbidity, on the mortality of $C$. fluminea. A docking device was designed which consisted of mounting an electric water pump to a hydraulic system consisting of connected water pipes (Fig.3) to ensure water circulation in a closed system and maintain the desired levels of turbidity constant in the 10 tanks, as described below. The abiotic factors measured in the field, were reproduced in 10 aquariums in the experiment.

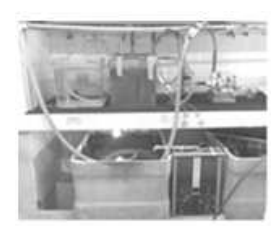

A

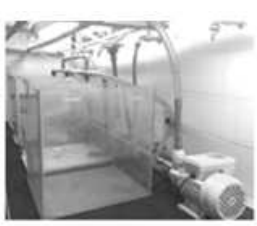

B

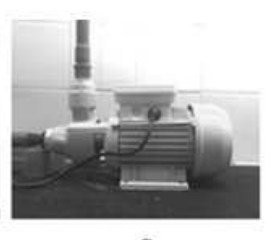

C
Figure 3. Mill developed for closed circulation of water and maintenance of the turbidity of the experiment. A. Water circulation. B. Tanks. C. Pump

The water temperature was kept at $27^{\circ} \mathrm{C}$ and controlled by heat exchange with the cooled air of the laboratory; the oxygenation of the water was maintained between nine and10 $\mathrm{mg} / \mathrm{L}$, with the help of aerators; the electrical conductivity $(\mu \mathrm{S} / \mathrm{cm})$ was measured using a conductivity meter, calibrated to not exceed the minimum values of $50 \mu \mathrm{S} / \mathrm{cm}$ or maximum of $105 \mu \mathrm{S} / \mathrm{cm}$.

During the specimen collection, the highest turbidity value measured in river was 167 NTU (Mogi River), which determined the choice of an extreme turbidity limit of 250 NTU. A range of turbidity levels were used in the experiment of $0,100,150,200$ and 250 NTU, which were obtained through adding river sediment to the water tanks. The desired turbidity levels in the experiments was performed by addition of sediment taken from the river in which each group of animals was collected. Once the turbidity levels were calibrated, the experiments were 
conducted separately and thrice a day monitored using a turbidimeter device, as before described.

For the porpoise of the experiments, two hundred animals were collected in the Mogi-Guaçu River and other two hundred in the Pardo River. The animals provided by Mogi-Guaçu River were randomly assigned to five tanks (40 in each) with turbidity monitored at $0,100,150,200$ and 250 NTU. The 200 specimens collected in the Pardo River were distributed using the same procedure, resulting in five experimental groups with pre-determined turbidity levels. Once a day, one liter of a specially cultivated Chlorella $s p$ and Chlamydomonas $s p$ microalgae culture was added to each tank and readings were taken thrice a day, to ensure the stability of the water parameters.

The percentage mortality of individuals was recorded in each tank, after 24, 48, 72, 96 and 120 hours of experiment, and dead animals were removed from the tanks to have the palial cavity analyzed.

\subsection{Procedure to Analyze the Palial Cavity of $C$. Fluminea Specimens}

We chose specimens which had been submitted to turbidity levels of $200 \mathrm{NTU}$ and died in the experiment, to analyze the palial cavity. This methodology was chosen because this level of turbidity was the closest to that recorded in the field. It was also chosen because there was no significant differences, after 96 hours of exposure, between the mortality rates of specimens at 150,200 and 250 NTU (see homogeneity test). In this way, in every 24 hours, the $C$. fluminea specimens that had died within the period were fixed and sorted by time of exposure to turbidity (Fig. 4).

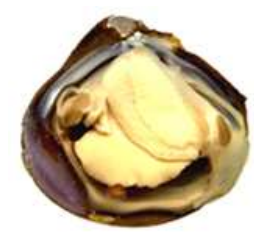

A.

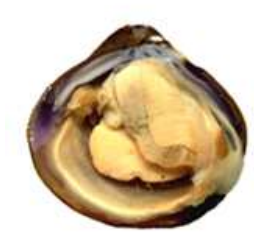

D.

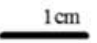

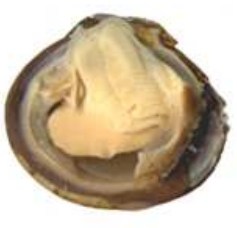

B.

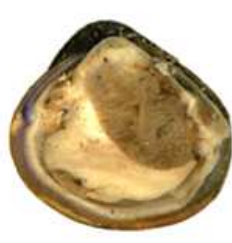

E.

F.
Figure 4. Scans of dissected specimens at various exposure times.A. control.B. 24 hours. C. 48 hours. D. 72 hours. E. 96 hours. F. 120 hours.

Dead specimens were then dissected in the following manner: their anterior and posterior adductor muscles were cut and the right valve removed, exposing the right face of the soft tissue while keeping the left valve intact. The specimen was subsequently submerged in water in a petri dish. Each petri dish was then placed on the scanner table and images were obtained at a resolution of 1,200 dpi. Images were further processed using Adobe ${ }^{\circledR}$ Photoshop $\AA$, in order to isolate only the image of interest.

\section{Results}

Monitoring of abiotic components was carried out at both collection points from October 2007 to October 2008 (see Figs 1 and 2). In this rainy season, there was an increase in not only the electrical conductivity, but also the turbidity levels of both rivers. However, these increases were more significant in absolute terms in the Mogi-Guaçu River.

Daniel's homogeneity test [20] was used to analyze whether there were significant differences (at a significance level of 5\%) in mortality between the specimens from the rivers Pardo and Mogi Guaçu for the three levels of turbidity (150, 200 and 250) over a period of 96 hours and 120 hours and results were: 4.1758 (Pardo, 96 hrs.), 1.3636 (Pardo, 120hrs), 3.0861 (Mogi-Guaçu, 96hrs) and 0.8333 (Mogi Guaçu, 120hrs). The value distribution tabulated in $\chi^{2}$ (2) is 5.99 for the significance level of 5\%. In this regard, the values obtained were lower than in the tests tabulated value, implying that there was no significant difference in the mortality rates for both exposure times to turbidity (96 and 120 hours) at rates of 150, 200 and 250 NTU (see Tables 1 and 2), for both samples of animals from the rivers Pardo and Mogi-Guaçu. Over 50\% of specimens exposed to turbidity levels of $100 \mathrm{NTU}$ remained alive for more than seven days.

Table 1. Percentage mortality of C. fluminea, collected in the Mogi Guaçu River, exposed to different levels of turbidity, for sediment origin. Values represent the mean of three replicates $(n=600)$.

\begin{tabular}{cccccc}
\hline \multirow{2}{*}{ Time (hours) } & \multicolumn{5}{c}{ Turbidity (NTU) } \\
\cline { 2 - 6 } & $\mathbf{0}$ & $\mathbf{1 0 0}$ & $\mathbf{1 5 0}$ & $\mathbf{2 0 0}$ & $\mathbf{2 5 0}$ \\
\hline $\mathbf{2 4}$ & 0 & 0 & 0 & 0 & 0 \\
$\mathbf{4 8}$ & 0 & 0 & 0 & 0 & 0 \\
$\mathbf{7 2}$ & 0 & 0 & 2,5 & 0 & 2,5 \\
$\mathbf{9 6}$ & 0 & 2,5 & 30 & 47,5 & 32,5 \\
$\mathbf{1 2 0}$ & 0 & 20 & 55 & 60 & 65 \\
\hline
\end{tabular}

Table 2. Percentage mortality of C. fluminea, collected in the Pardo River, exposed to different levels of turbidity, for sediment origin. Values represent the mean of three replicates $(n=600)$.

\begin{tabular}{cccccc}
\hline \multirow{2}{*}{ Time (hours) } & \multicolumn{5}{c}{ Turbidity (NTU) } \\
\cline { 2 - 6 } & $\mathbf{0}$ & $\mathbf{1 0 0}$ & $\mathbf{1 5 0}$ & $\mathbf{2 0 0}$ & $\mathbf{2 5 0}$ \\
\hline $\mathbf{2 4}$ & 0 & 0 & 0 & 2,5 & 5 \\
$\mathbf{4 8}$ & 0 & 0 & 2,5 & 0 & 0 \\
$\mathbf{7 2}$ & 0 & 0 & 10 & 5 & 17,5 \\
$\mathbf{9 6}$ & 0 & 2,5 & 40 & 22,5 & 42,5 \\
$\mathbf{1 2 0}$ & 0 & 25 & 62,5 & 57,5 & 70 \\
\hline
\end{tabular}

Further, by the observation of the palial cavity, we found clear evidence of the presence of sediment (Fig. 4). It should be noted, however, that this procedure could not provide an exact particle-size or volume of how much sediment entered the cavity, as fixation procedures and 
subsequent handling of the specimen during dissection, mounting and scanning will interfere with these values. After the experiments, surviving animals were sacrificed and disposed of as hospital discharge.

\section{Discussion}

The increase in turbidity in both sites is caused by erosion occurring upstream of the points studied, particularly in regions where the buffer zones have been depleted (riparian vegetation). This erosion sets off a chain of hydro-sedimentological processes, which culminate in a number of environmental problems. Thus, the abiotic parameters of the watersheds for the period studied can be explained by the increase in the flow measurement, which causes the resuspension of not only sediment particles, but also organic matter and chemical elements which had been deposited in the riverbeds. This is further aggravated by the discharge of domestic sewage; industrial effluents; and organic matter and various solutes from agricultural activities, which are deposited into the rivers via runoff. This helps to explain a seasonal decline in the population especially in during the period of intense hydro-meteorological events (November-January).

Both watersheds studied have a high potential erosion risk. This characteristic in a result of several key features which include: inadequate soil management; lack of riparian cover; monoculture; soils which are susceptible to erosion; and the high frequency and intensity of hydro-meteorological events [21]. These key features combine to increase erosion and carry sediment to the rivers [6].

In studies conducted in these two particular watersheds [22], an increased mortality rate of $C$. fluminea was observed during the rainy season, leading to a reduction in the local population. In preliminaries studies, we modelled the risk of mortality of $C$. fluminea as a function of elevated turbidity in the river of origin using multivariate logistic regression, and our results supported the idea that an increase in turbidity levels can be linked to higher mortality rates for the species $C$. fluminea.

Experimentally, in this study, a mortality rate between 30 to $70 \%$ of the sample was recorded amongst specimens from both rivers after having been subjected to the experimental conditions in the range between 150 to 250 NTU, with an important percentage of deaths, starting at 96 hours of exposure (see Tables 1 and 2). The mortality rate observed in the experiments may be similar to that occurs under natural conditions, considering turbidity levels measured in both rivers during the rainy season [22]. This study found data to support the idea that increases in turbidity levels, in nature, (over $150 \mathrm{UNT}$ ) can be linked to higher mortality rates for the species, C.fluminea, when exposed to these conditions for over 96 hours.

Rainfall occurring over long periods in the watershed, whether continuous or with brief interruptions [22], can raise turbidity levels for several days, dramatically increasing the amount of time the $C$. fluminea is exposed to elevated levels of turbidity, originated by runoff [6]. The increase in turbidity appears to be dramatic for the $C$. fluminea, and can induce the animals behave in such a way as to prevent the opening of the valve, i.e. immobilizing it. This presumed immobility is associated with the absence of feeding and gas exchange with the environment, which could contribute to the lethargy of animals, allow fine sediment to enter into the palial cavity and eventually lead to death.

Results suggested that not only the turbidity levels, but also the time of exposure, were significant variables in explaining mortality. This helps to explain a seasonal decline in the population, especially in during the period of intense hydro-meteorological events (November-January) i.e. the rainy season, in both watersheds studied. Even so, there are strong indicators to suggest that this sediment is a factor in the mortality of $C$. fluminea. Specimens in the control group showed no alterations in the palial cavity examination.

The results of this study also may indicate that the animals lose their ability to avoid adverse environmental stimuli, either by burial or horizontal displacement, deficiency of oxygen [23] or competition for space [4] and that suspended sediment and turbidity [7] contribute significantly to the decline of aquatic organisms populations.

\section{Conclusions}

A systemic analysis of the results points to the characteristics of the watershed surrounding the main study site as having a significant effect on the composition of the $C$. fluminea community and their environment, and therefore leading to a decline in the local population of the species.

It is possible that the intensification of erosion processes, driven by various rural economic activities in the watersheds studied, and a subsequent increase in turbidity, could be one of the probable causes of the decline of the bivalves studied, as well as the decline of native mollusk biodiversity, as noticed in Brazilians watersheds.

\section{References}

[1] C.F. Ituarte, "Primeira noticia acerca de la presencia de pelecípodos asiáticos em el área rio-platense". Neotropica, vol. 27, pp. 79-82, 1981. (In Spanish).

[2] M.C.D. Mansur, and L.M.M.P. Garces, "Ocorrência e densidade de Corbicula fluminea (Muller, 1774) e Neocorbicula limosa (Matton, 1811) na Estação Ecológica do Taim e áreas adjacentes, Rio Grande do Sul, Brasil (Mollusca, Bivalvia, Corbiculidae)”. Iheringia Série Zoologica, vol. 68, pp. 95-115, 1988. (In Portuguese).

[3] S.E. Belanger, J.L. Farris, D.S. Cherry and JR. J Cairns, "Sediment preference of the freshwater Asiatic clam Corbicula fluminea". The Nautilus, vol. 99, pp. 66-72, 1985.

[4] P.W. Kat, "Effects of population density and substratum type on growth and migration of Elliptio complanata (Bivalvia:Unionidade)", Malacological Review, vol. 15, pp. 119-127, 1982. 
[5] A. Christofoletti, "Geomorfologia Fluvial". Edgar Blucher Ltda, São Paulo, BR, 1981. (In Portuguese).

[6] F.F. Neves, F.G.B. Silva and S. Crestana, "Uso do modelo AVSWAT na avaliação do aporte de nitrogênio $(\mathrm{N})$ e fósforo (P) aos mananciais de uma microbacia hidrográfica contendo atividade avícola". Engenharia Sanitária e Ambiental, vol. 11, pp. 311-317, 2006. (In Portuguese).

[7] W.F. Henley, M.A.A. Patterson, R.J. Neves and A.D. Lemly, "Effects of sedimentation and turbidity on lotic food webs: A concise review for natural resources managers", Reviews in Fisheries Science, vol. 8, pp.125-139, 2000.

[8] K. E. Poole and J.A. Downing, "Relationship of declining mussel biodiversity to stream-reach and watershed characteristics in an agricultural landscape", Journal of the North American Benthological Society, vol. 23, pp.114-125, 2004.

[9] M.E. Österling, B.L. Arvidsson and L.A. Greenbert, "Habitat degradation and the decline of the threatened mussel Margaritifera margaritifera: influence of turbidity and sedimentation on the mussel and its host", Journal of Applied Ecology, vol. 47, pp. 759-768, 2010.

[10] E.F. Andersen, "Effects of land use and land cover on freshwater mussel populations in the upper Neuse River basin, NC: A GIS approach.” Thesis. North Carolina State University. State University, USA, 2002.

[11] N.J. Hebling, "The functional morphology of Anodontites trapezeus (Spix) and Anodontites trapesialis (Lamarck) (Bivalvia: Mycetopodidae)", Boletim de Zoologia, vol. 15, pp. 265-298, 1976. (In Portuguese).

[12] W.E.P. Avelar and S.C.D. Santos, "Functional anatomy of Castalia undosa undosa (Martens, 1827) (Bivalvia: Hyriidae)", The Veliger, vol. 34, pp. 21-31, 1991.

[13] W.E.P. Avelar, "Functional anatomy of Fossula fossiculifera (D’Orbigny, 1843) (Bivalvia: Mycetopodidae)", American Malacological Bulletin, vol. 10, pp.129-138, 1993.

[14] L.R.L. Simone, "Anatomical characters and systematics of Anodontites trapesialis (Lamarck, 1819) from South America (Mollusca, Bivalvia, Unionoida, Muteloidea)", Studies on Neotropical Fauna and Environment, vol. 29, pp. 169-185, 1994.
[15] L.R.L. Simone, "Anatomy and systematics of Anodontites elongatus (Swaison) from Amazon and Paraná basins, Brazil (Mollusca, Bivalvia, Unionoida, Mycetopodidae)", Revista Brasileira de Zoologia, vol. 14, pp. 877-888, 1997.

[16] W.E.P. Avelar and A.D. Cunha, "The anatomy and functional morphology of Diplodon rhombeus fontainianus (Orbigny, 1835) (Mollusca, Bibalvia, Hyriidae)”, Brazilian Journal of Biology, vol. 69, pp.1153-1163, 2009.

[17] S. Peredo and E. Parada, "Reprodutive cycle in the freshwater mussel Diplodon chilensis chilensis (Mollusca: Bivalvia)", The Veliger, vol. 28, pp. 418-425, 1986.

[18] W.E.P. Avelar, A.S. Costa, A.J. Colusso and C.M.R. DalBó, "Sexual dimorphism in Castalia undosa undosa Martens, 1827 (Bivalvia: Hyriidae)”, The Veliger, vol. 34, pp. 229-231, 1991.

[19] W.E.P. Avelar, S.H.S.T. Mendonça, "Aspects of gametogenesis of Diplodon rotundus gratus (Wagner, 1827) (Bivalvia: Hyriidae) in Brazil", American Malacological Bulletin, vol. 14, pp.157-163, 1998.

[20] W.W. Daniel, "Biostatistics: a foundation for analysis in the health sciences", Wiley, New York, USA, 1974.

[21] F.F. Neves, "Avaliação da influência de sedimentos em suspensão em populações de Corbicula fluminea (MÜLLER, 1774) (Mollusca, Bivalvia, Corbiculidae): análise comparativa em duas microbacias hidrográficas do Estado de São Paulo, Brasil." Tese - Faculdade de Filosofia, Ciências e Letras de Ribeirão Preto, Universidade de São Paulo, Ribeirão Preto, Brasil, 2010. (In Portuguese).

[22] M.P. Vianna, "Aspectos da biologia de Corbicula fluminea (Müller, 1774) (Mollusca, Bivalvia, Corbiculidae) em duas bacias hidrográficas do Estado de São Paulo, Brasil.” Tese. Faculdade de Filosofia, Ciências e Letras de Ribeirão Preto, da Universidade de São Paulo. Brasil, 2009. (In Portuguese).

[23] A.E. Brafield, "The effects of oxygen deficiency on the behavior of Macoma balthica (L.), Aninal Behaviour, vol. 11, pp. 345-346, 1963. 